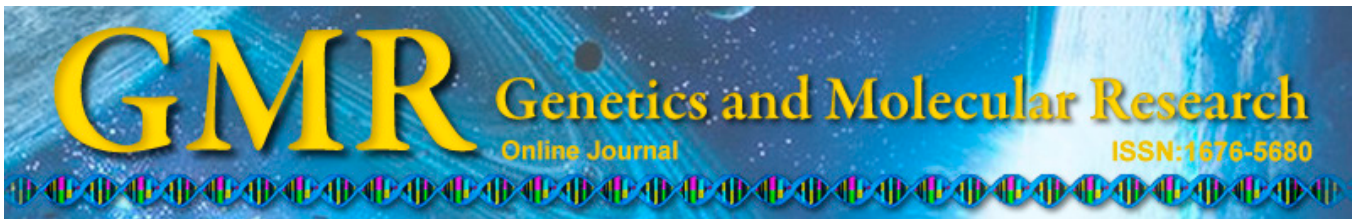

\title{
Identification of transgenic cloned dairy goats harboring human lactoferrin and methylation status of the imprinted gene IGF2R in their lungs
}

Y.L. Zhang, G.M. Zhang, Y.J. Wan, R.X. Jia, P.Z. Li, L. Han, F. Wang and M.R. Huang

Jiangsu Livestock Embryo Engineering Laboratory, Nanjing Agricultural University, Nanjing, China

Corresponding author: M.R. Huang

E-mail: caeet@njau.edu.cn

Genet. Mol. Res. 14 (3): 11099-11108 (2015)

Received January 19, 2015

Accepted May 14, 2015

Published September 22, 2015

DOI http://dx.doi.org/10.4238/2015.September.22.3

\begin{abstract}
Dairy goat is a good model for production of transgenic proteins in milk using somatic cell nuclear transfer (SCNT). However, animals produced from SCNT are often associated with lung deficiencies. We recently produced six transgenic cloned dairy goats harboring the human lactoferrin gene, including three live transgenic clones and three deceased transgenic clones that died from respiratory failure during the perinatal period. Imprinted genes are important regulators of lung growth, and may be subjected to faulty reprogramming. In the present study, first, microsatellite analysis, PCR, and DNA sequence identification were conducted to confirm that these three dead kids were genetically identical to the transgenic donor cells. Second, the $\mathrm{CpG}$ island methylation profile of the imprinted insulinlike growth factor receptor $(I G F 2 R)$ gene was assessed in the lungs of the three dead transgenic kids and the normally produced kids using bisulfite sequencing PCR. In addition, the relative mRNA level of
\end{abstract}


$I G F 2 R$ was also determined by real-time PCR. Results showed that the $I G F 2 R$ gene in the lungs of the dead cloned kids showed abnormal hypermethylation and higher mRNA expression levels than the control, indicating that aberrant DNA methylation reprogramming is one of the important factors in the death of transgenic cloned animals.

Key words: Transgenic cloned dairy goats; Lung; DNA methylation; $I G F 2 R$; mRNA expression

\section{INTRODUCTION}

Somatic cell nuclear transfer (SCNT) technology offers a new method of transgenic research in domestic animals, and an increasing number of transgenic domestic animals have been produced using SCNT (Cibelli et al., 1998; Bondioli et al., 2001; Behboodi et al., 2004; Huang et al., 2007). However, the low efficiency of SCNT methods appears to be a great barrier to the production of such potentially highly valuable transgenic livestock (Jang et al., 2006; Yang et al., 2007). During SCNT, the original epigenetic pattern in differentiated somatic cells is first erased and then embryonic epigenetic characteristics and gene expression patterns are re-established to a totipotent embryonic state, followed by cloned embryos of totipotent status being re-differentiated to various somatic cell types during later development. This process, which involves various epigenetic modifications, is called nuclear reprogramming (Yang et al., 2007). It has been proposed that aberrant nuclear reprogramming results in developmental anomalies and low cloning efficiency (Jaenisch and Bird, 2003; Wei et al., 2010).

DNA methylation is a principal epigenetic modification of the genome and plays a critical role in nuclear reprogramming (Feng et al., 2006). It mainly occurs at the 5 'cytosine in CpG dinucleotides, which are usually found in clusters, termed CpG islands (Gardiner-Garden and Frommer, 1987). An imprinted gene is expressed from a single allele, depending on whether it was the maternally or paternally inherited copy, which is regulated primarily by DNA methylation in the imprinting control region (ICR). Most imprinted genes play roles in regulating fetal development, and aberrant imprinting leads to developmental anomalies (Zhang et al., 2009; Su et al., 2011; Zhao et al., 2012). The insulin-like growth factor receptor (IGF2R) gene is maternally expressed and functions to suppress fetal growth by acting as a scavenger receptor for the imprinted fetal mitogen IGF2 (Li et al., 2007; Suteevun-Phermthai et al., 2009). It has been reported that $I G F 2 R$ messenger RNA was significantly reduced in various organs of in vitro fertilized sheep with fetal overgrowth (Young et al., 2001). IGF2R is well conserved in mammals, including goats. A number of studies have reported aberrant expression of $I G F 2 R$ in mice, cattle, and sheep, but related research on transgenic cloned goats is limited.

The present study aims to investigate the $\mathrm{CpG}$ island methylation profile and relative expression level of the $I G F 2 R$ gene in deceased cloned transgenic dairy goats. Cloned goats are particularly likely to display symptoms of respiratory failure and we suggest that the observed highly variable methylation patterns of $I G F 2 R$ may reflect a very low efficiency of reprogramming in the lung.

\section{MATERIAL AND METHODS}

Unless otherwise indicated, all chemicals used in this study were obtained from 
Sigma-Aldrich (St. Louis, MO, USA) and the media from the Gibco Invitrogen Corporation (Grand Island, NY, USA). All trials were conducted in accordance with the Guidelines for the Care and Use of College of Animal Science and Technology, Nanjing Agricultural University.

\section{Production of transgenic dairy goats by SCNT}

Construction of the human lactoferrin $(h L F)$ gene vector and preparation of competent $h L F$ transgenic fibroblast cells were conducted as detailed in our previously published paper (Meng et al., 2011). Oocyte collection and in vitro maturation, SCNT, activation of reconstructed embryos, culture of cloned embryos, embryo transfer, and pregnancy diagnosis were performed as described previously (Lazaris et al., 2006; Zhang et al., 2010).

Briefly, oocytes were recovered from abattoir-derived ovaries and matured in vitro in TCM199 medium supplemented with $10 \% \mathrm{FBS}, 10 \mu \mathrm{g} / \mathrm{mL}$ FSH, $10 \mu \mathrm{g} / \mathrm{mL} \mathrm{LH}, 1$ $\mu \mathrm{g} / \mathrm{mL} \mathrm{E}_{2}$, and $100 \mathrm{IU} / \mathrm{mL}$ penicillin/streptomycin for 20 to $22 \mathrm{~h}$ at $38^{\circ} \mathrm{C}$ under $5 \% \mathrm{CO}_{2}$ in humidified air. Then, oocytes with an extruded first polar body were selected and stained with $10 \mu \mathrm{g} / \mathrm{mL}$ Hoechst 33342 for $10 \mathrm{~min}$ prior to enucleation. The first polar body and the small amount of surrounding cytoplasm were removed from oocytes with a glass pipette in PBS microdrops.

Following enucleation, a small $(<20 \mu \mathrm{m}) \mathrm{hLF}$ transgenic fibroblast cell with a smooth plasma membrane was injected into the perivitelline space of each enucleated oocyte by micropipette. Nuclear transfer (NT) couplets were electrically fused in medium comprised of $0.3 \mathrm{M}$ mannitol, $0.5 \mathrm{mM} \mathrm{MgSO} \cdot \cdot 7 \mathrm{H}_{2} \mathrm{O}, 0.1 \mathrm{mM} \mathrm{CaCl}_{2}, 0.5 \mathrm{mM}$ HEPES, and $1 \mathrm{mg} / \mathrm{mL} \mathrm{BSA}$, by applying a single electric pulse $(20 \mu \mathrm{s}$ each, $1.2 \mathrm{kv} / \mathrm{cm})$. Activation of fused embryos was achieved chemically by incubation in $5 \mu \mathrm{M}$ ionomycin for $5 \mathrm{~min}$, followed by post-activation in $2 \mathrm{mM}$ 6-DAMP for $4 \mathrm{~h}$. After activation treatments, NT embryos were cultured in SOFaa at $38.5^{\circ} \mathrm{C}$ in a $5 \% \mathrm{CO}_{2}$ atmosphere.

Reconstructed embryos were cultured in vitro for $24 \mathrm{~h}$, and surgically transferred into the oviduct of the synchronized foster-mother goats. Of the six cloned transgenic kids that were born, three were born alive and three died during the perinatal period (named TD1, TD2, and TD3 clones).

\section{Identification of transfected cloned goats}

Genomic DNA was extracted from tissue collected from the three NT-derived kids that died during the perinatal period and the recipient goats, and analyzed using five microsatellite markers (Table 1) using methods described elsewhere (Chen et al., 2007). The microsatellite alleles for the NT-derived offspring were compared with those from transfected goat donor cells and contrasted with those from the recipient goats that carried the respective pregnancies.

Goat ear cells, donor cells, and surrogate skin cells were resuspended in lysis buffer, incubated at $55^{\circ} \mathrm{C}$ for $5 \mathrm{~h}$, and heated to $95^{\circ} \mathrm{C}$ for $10 \mathrm{~min}$ in order to inactivate the proteinase $\mathrm{K}$. Genomic DNA was amplified in a $20-\mu \mathrm{L}$ reaction volume with the following variables: 30 cycles of $1 \mathrm{~min}$ at $95^{\circ} \mathrm{C}, 1 \mathrm{~min}$ at $62^{\circ} \mathrm{C}$, and $1 \mathrm{~min}$ at $72^{\circ} \mathrm{C}$, and a final 10 -min extension period at $72^{\circ} \mathrm{C}$. A PCR primer set was used to amplify the 750-bp hLF gene. The forward and reverse primers are as follows: 5'-GAATGGCTGGCAGTGAAACA-3' and 5'-CTCAATGGG CTCAGGTGGAC-3' (Table 1). 
Table 1. Five microsatellite markers and their primers of target sequences.

\begin{tabular}{llc}
\hline Microsatellite loci & Sequence (5'-3') & Length (bp) \\
\hline CP34 & 5'-GCTGA ACAAT GTGAT ATGTT CAGG-3' & 24 \\
& 5'-GGGAC AATAC TGTCT TAGAT GCTGC-3' & 25 \\
MAF65 & 5'-AAAGG CCAGA GTATG CAATT AGGAG-3' & 25 \\
INRA063 & 5'-CCACT CCTCC TGAGA ATATA ACATG-3' & 25 \\
& 5'-ATTTG CACAA GCTAAATCTA ACC-3' & 23 \\
INRA011 & 5'-AAACC ACAGA AATGC TTGGA AG-3' & 22 \\
& 5'-CGAGT TTCTT TCCTC GTGGT AGGC-3' & 24 \\
BMS1290 & 5'-GCTCG GCACA TCTTC CTTAG CAAC-3' & 24 \\
& 5'-TTGGC ACTTA CTACC TCATA TGTT-3' & 24 \\
& 5'-TTTTC TGGAT GTTGA GCCTA TT-3' & 22 \\
\hline
\end{tabular}

\section{Bisulfite sequencing-PCR analysis of IGF2R}

Genomic DNA was extracted from the lungs of the three deceased transgenic cloned kids and the normally produced kids using the TIANamp Genomic DNA Kit (Tiangen, Beijing, China), and this was followed by sodium bisulfite treatment using the Methylation-Gold ${ }^{\mathrm{TM}}$ Kit. Subsequently, the modified DNA sample was immediately used in bisulfite sequencing PCR (BSP) or stored at $-80^{\circ} \mathrm{C}$.

Specific primers, which were designed using MethPrimer, were used for the BSP amplification of IGF2R. Details of BSP-amplified nucleotide sequences of the IGF2R ICR are shown in Figure 1. PCR was performed with a DNA engine (Bio-Rad, USA) using the following program: $5 \mathrm{~min}$ at $95^{\circ} \mathrm{C}$, followed by 40 cycles of denaturation for $30 \mathrm{~s}$ at $95^{\circ} \mathrm{C}$, annealing for $30 \mathrm{~s}$ at $51^{\circ} \mathrm{C}$, and extension for $30 \mathrm{~s}$ at $72^{\circ} \mathrm{C}$. A final extension was run at $72^{\circ} \mathrm{C}$ for 5 min. The PCR products were gel-purified using the AxyPrep Purification Kit (Axygen, USA). The purified fragments were subcloned into pMD18-T vectors (TaKaRa, Japan). The clones confirmed by PCR were sequenced. We sequenced ten clones from each independent set of amplification and cloning. BSP results and C-T conversion rate were analyzed by the BIQAnalyzer software (http://biq-analyzer.bioinf.mpi-inf.mpg.de/). To ensure data quality, we chose sequences for which the $\mathrm{C}-\mathrm{T}$ conversion rate was greater than 95\% (Figure 1).

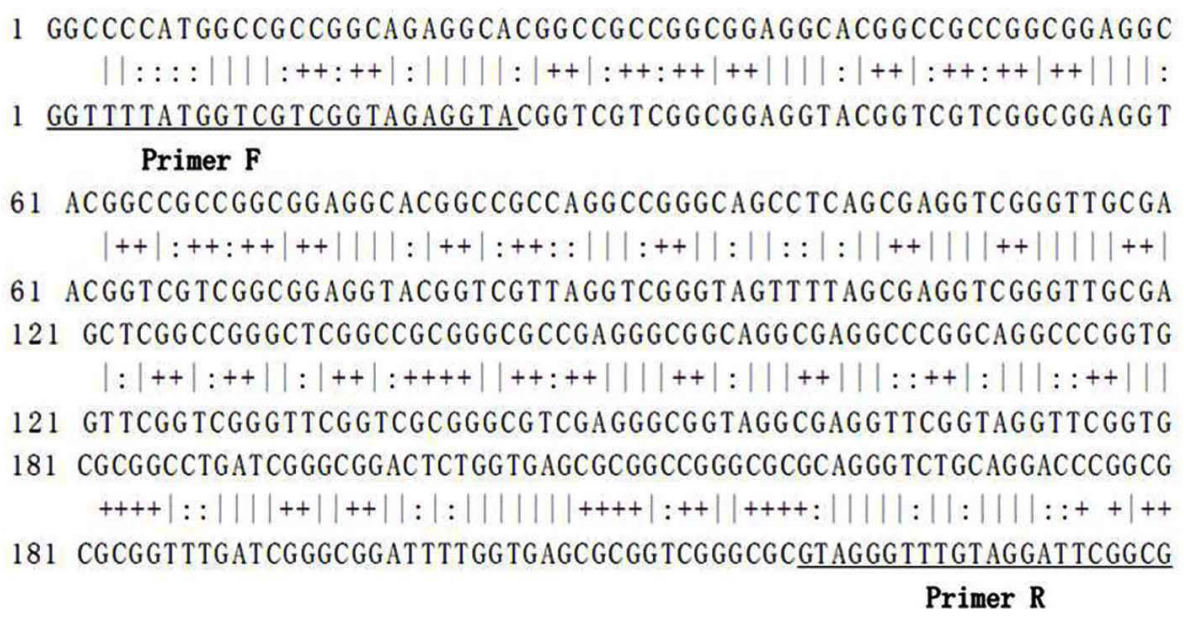

Figure 1. BS-PCR-amplified nucleotide sequences of IGF2R ICR. Primer sequences are underlined. 


\section{Real-time PCR analysis of IGF2R expression}

Quantification of all transcripts was performed by real-time quantitative PCR (RTPCR) using the ABI 7300 PRISM system (Applied Biosystems, Foster City, CA, USA). The forward and reverse primers for $I G F 2 R$ are as follows: F: 5'-CCAGCGTCTGTGACTTCG TG-3' and R: 5'-CCATCCTTGCAGCCTCCTTC-3'. PCR products for the IGF2R gene were detected by SYBR Green chemistry. PCRs were run as triplicates in a total volume of $20 \mu \mathrm{L}$, which consisted of SYBR Green PCR master mix (Applied Biosystems), $250 \mathrm{nM}$ of each sequence-specific primer, and 100 cell equivalent of cDNA. The amplification conditions were as follows: preincubation for optimum uracil-N-glycosylase activity at $50^{\circ} \mathrm{C}$ for $2 \mathrm{~min}$, DNA polymerase activation at $95^{\circ} \mathrm{C}$ for $10 \mathrm{~min}$, followed by 45 amplification cycles at $95^{\circ} \mathrm{C}$ for $15 \mathrm{~s}$, and $60^{\circ} \mathrm{C}$ for $45 \mathrm{~s}$. At the end of the amplification cycles, a melting curve analysis was performed to verify specific amplification.

The comparative $\mathrm{C}_{\mathrm{T}}$ method was used for relative quantification of $I G F 2 R$ gene expression levels (ABI Prism Sequence Detection System, Applied Biosystems).

The quantity of each measured cDNA sample was normalized to the endogenous gene GAPDH (a house-keeping gene) and all samples were measured in triplicate.

\section{Statistical analysis}

Methylation and mRNA expression levels of $I G F 2 R$ were analyzed using one-way ANOVA in the package SPSS 16.0 software (SPSS Inc., Chicago, IL, USA). The data are reported as means \pm standard error (SE). Statistical differences were considered to be significant when $\mathrm{P}<0.05$.

\section{RESULTS}

\section{Microsatellite and PCR analysis of transgenic cloned dairy goats}

Two to eight cell stage cloned embryos were produced (Figure 2) and implanted into recipient goat oviducts (10 embryos per female), as shown in Table 2. Six kids were produced, but three of these died during the perinatal period. Five pairs of polymorphic primers CP34, MAF65, INRA063, INRA011, and BMS1290 were used to detect the genotype of the three transgenic cloned kids that died during the perinatal period, the donor cells, and the surrogate goats. The polymorphic results of the microsatellite DNA showed that the three deceased kids had the same genotype as the transfected donor cell, but a different genotype to the pregnant goats (Table 3). Meanwhile, the presence of the $h L F$ gene in the kids was also confirmed by PCR and DNA sequence analysis from ear cells of the kids (Figures 2 and 3; Tables 2 and 3).

\section{DNA methylation analysis of the imprinted gene IGF2R by BSP}

The putative differential methylation region (DMR) of the goat $I G F 2 R$ gene was located between nucleotides 244 and 475 of intron 2. The DNA methylation levels of $I G F 2 R$ ICR analyzed by BSP in the dead transgenic cloned kids and the control kid are shown in Figure 4. IGF2R exhibited significantly higher methylation levels in the lungs of TD1 (79.05 
$\pm 1.34 \%)$, TD2 $(80.25 \pm 0.35 \%)$, and TD3 $(98.45 \pm 2.19 \%)$ compared to the lungs of agematched controls $(I G F 2 R=10.7 \pm 0.99 \%, \mathrm{P}<0.05)$. Therefore, an aberrant methylation pattern appears to occur in the imprinted gene $I G F 2 R$ in the lungs of dead cloned kids (Figure 4).
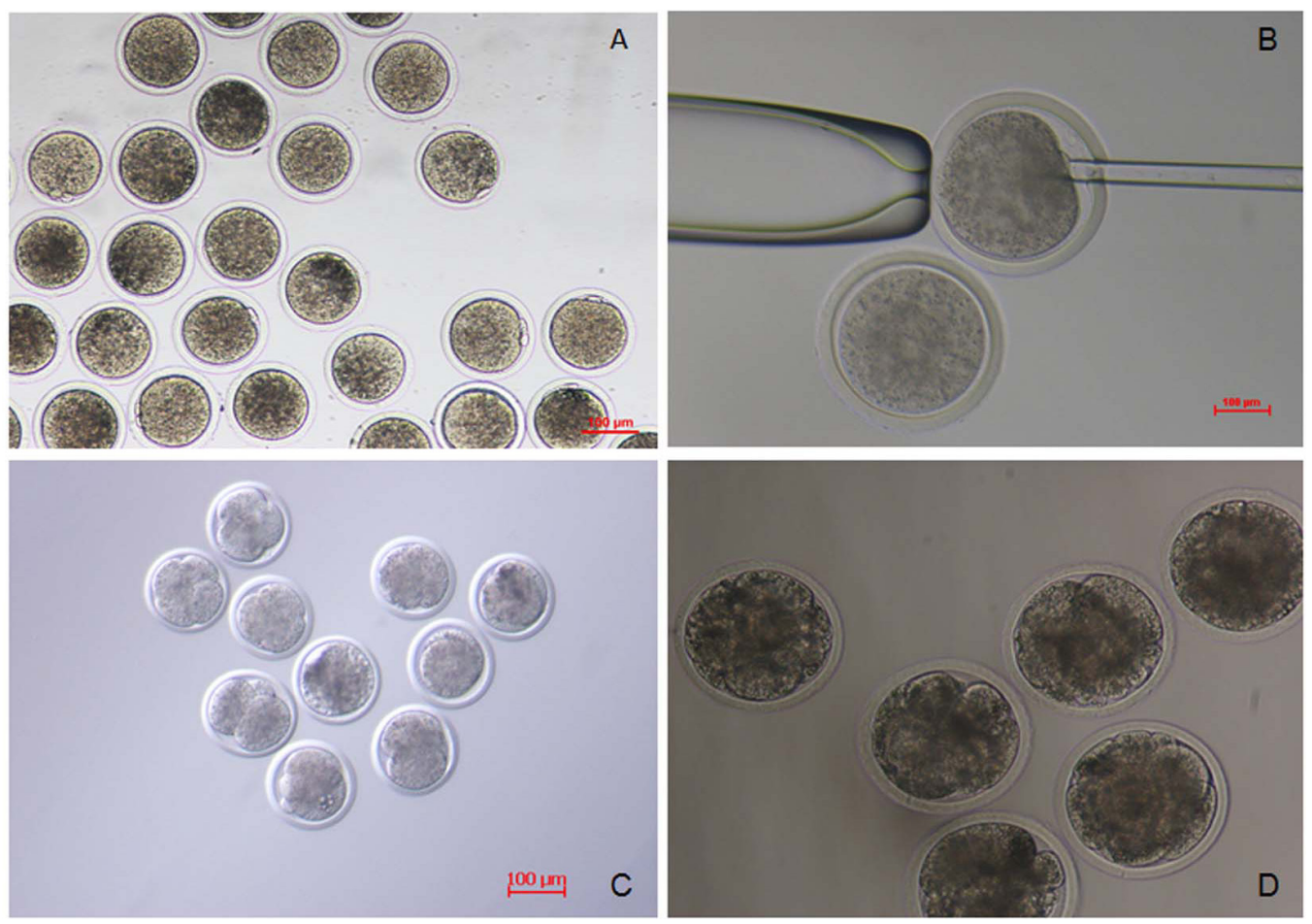

Figure 2. Production of goat-cloned embryos. A. Mature goat oocytes (100X); B. the enucleation of goat oocytes (200X); C. and D. 2-8 cell (100X, 200X, respectively).

Table 2. Embryo transfer of goat hLF transgenic embryo.

\begin{tabular}{lcccc}
\hline $\begin{array}{l}\text { Embryo } \\
\text { development stage }\end{array}$ & $\begin{array}{c}\text { No. of } \\
\text { recipient goats }\end{array}$ & $\begin{array}{c}\text { No. of } \\
\text { implanted embryos }\end{array}$ & $\begin{array}{c}\text { No. of } \\
\text { pregnant goats (\%) }\end{array}$ & $\begin{array}{c}\text { No. of } \\
\text { pregnancy to term (\%) }\end{array}$ \\
\hline $2-8$ cell & 46 & 462 & $9(18.37)$ & $6(13.04)$ \\
\hline
\end{tabular}

Table 3. Five microsatellite locus analyses of tissue samples from cloned goats and their fosters.

\begin{tabular}{|c|c|c|c|c|c|c|c|}
\hline Samples & Donor cell & Cloned Goat 1 & Recipient 1 & Cloned Goat 2 & Recipient 2 & Cloned Goat 3 & Recipient 3 \\
\hline CP34 & $108 / 116$ & $108 / 116$ & $116 / 118$ & $108 / 116$ & $116 / 120$ & $108 / 116$ & $120 / 130$ \\
\hline MAF65 & $117 / 131$ & $117 / 131$ & $121 / 135$ & $117 / 131$ & $121 / 132$ & $117 / 131$ & $132 / 136$ \\
\hline INRA063 & $166 / 166$ & $166 / 166$ & $162 / 164$ & $166 / 166$ & $164 / 170$ & $166 / 166$ & $162 / 164$ \\
\hline INRA011 & $248 / 248$ & $248 / 248$ & $214 / 226$ & $248 / 248$ & $217 / 224$ & $248 / 248$ & $214 / 223$ \\
\hline BMS 1290 & $90 / 102$ & $90 / 102$ & $106 / 108$ & $90 / 102$ & $164 / 174$ & $90 / 102$ & $102 / 108$ \\
\hline
\end{tabular}




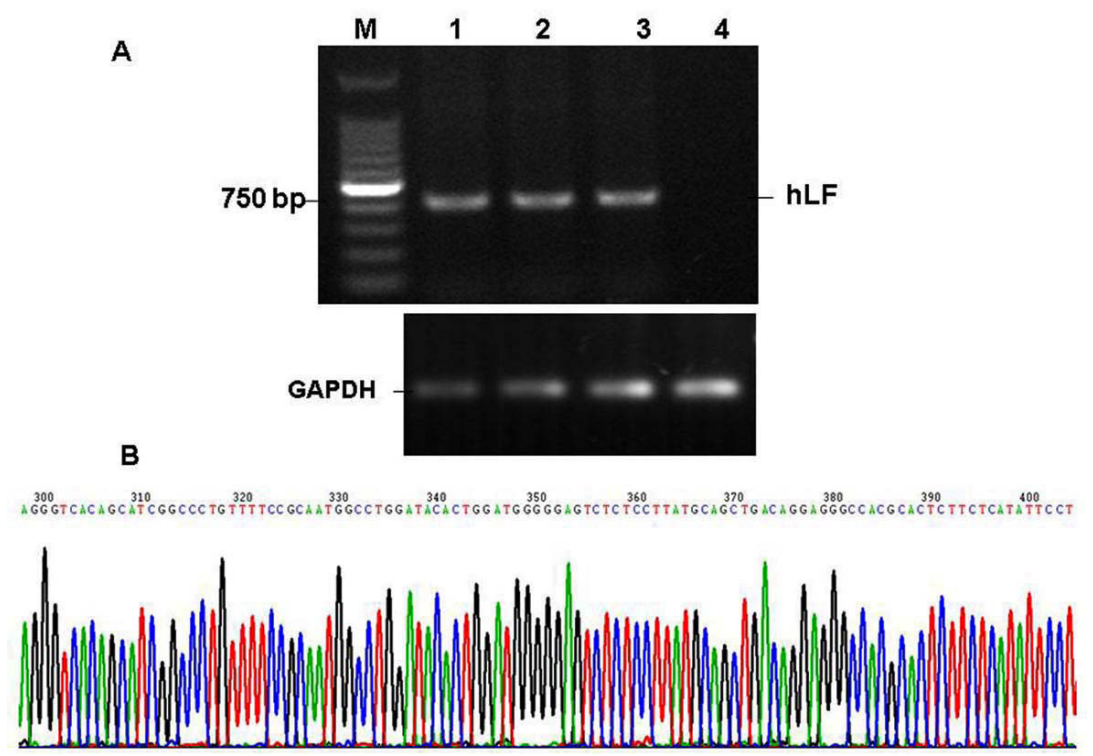

Figure 3. Identification of the hLF gene in the cloned goats. A. hLF and GAPDH gene amplification by PCR, respectively. Lanes 1-3=Cloned kids; lane $4=$ recipient goat as negative control; lane $M=$ DNA marker. B. DNA sequence identification of the decreased cloned goats.

A

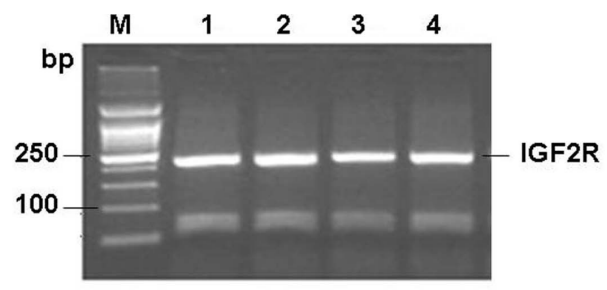

B

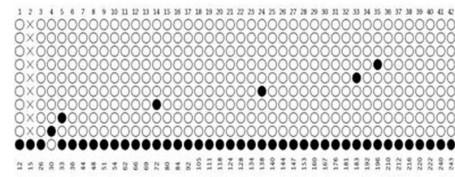

Control

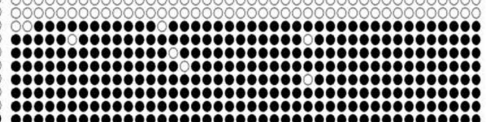

TD1

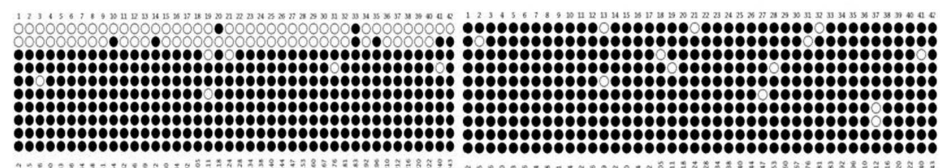

TD2

TD3

Figure 4. DNA methylation status of IGF2R in lung of deceased transgenic cloned lambs and normal control lamb, which were analyzed by BSP. A. Objective fragment of IGF2R in lung of dead cloned goat fetus and agematched common goat fetus. Lanes 1-3 = Lung of dead cloned goat fetus; lane $4=$ lung of age-matched common goat fetus; lane $M=$ DNA marker. B. Methylation profiles of IGF2R ICR in lungs of dead transgenic clones and normally produced goats. Unfilled (white) and filled (black) circles represent unmethylated and methylated CpGs, respectively. Horizontal lines of circles represent one separate clone that was sequenced. 


\section{mRNA expression levels of the imprinted gene IGF2R}

The relative expression levels of the $I G F 2 R$ gene were analyzed by quantitative RTPCR. The PCR-amplified products were identified by melting curve profile, and $2.5 \%$ agarose gel electrophoresis and sequencing. As shown in Figure 5, the relative expression levels of $I G F 2 R$ in the lungs of the dead transgenic clones (TD1, TD2, and TD3) compared with the age-matched control were $2.19,3.34$, and 6.97 , respectively, which was significantly higher (P $<0.05$ ) than in the control (Figure 5).

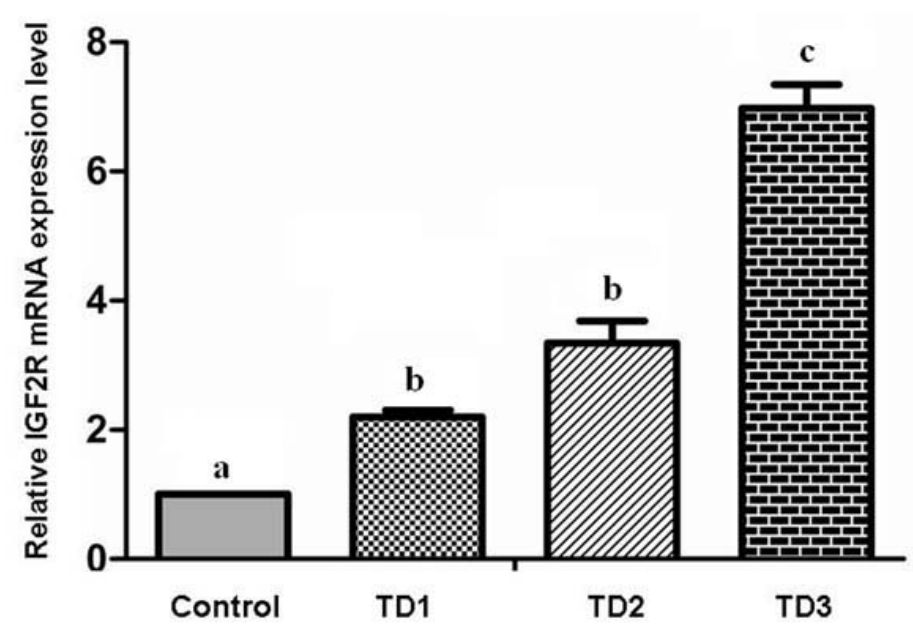

Figure 5. Relative expression of IGF2R in lung of deceased transgenic cloned lambs and normal control lamb, which were analyzed by RT- PCR. Each sample was analyzed in triplicate $(\mathrm{N}=3)$, and the standard deviations are reported as error bars. Values with different superscript $(a, b, c)$ differ significantly $(\mathrm{P}<0.05)$.

\section{DISCUSSION}

SCNT is a powerful tool demonstrating the developmental plasticity of differentiation cells. Incomplete remodification of the donor cell nucleus after NT probably leads to abnormal expression of developmentally important genes, which may cause low efficiency in animal cloning (Xing et al., 2007). Respiratory failure has frequently been described in cloned animals, but most of these studies were performed at the histological scale or gene expression level. In addition, most of the previous studies on abnormalities in cloned animals have been conducted on non-transgenic animals and the effects of the transgenic process on the epigenetic model of lungs in cloned offspring are still unknown. In the present study, we not only systematically analyzed $h L F$ gene integration in the deceased cloned goats, we also examined the DNA methylation levels and expression of the imprinted gene $I G F 2 R$ in the lungs of the deceased cloned kids to determine whether epigenetic modification of the imprinted gene was responsible for lung deficiencies and respiratory failure.

$I G F 2 R$ is a well-characterized negative regulator of $I G F-2$ that binds this growth factor and downregulates its activity by endocytosis and degradation. The maternally expressed imprinted gene $I G F 2 R$ is regulated by a differentially methylated ICR, which is located within the second intron of $I G F 2 R$. The ICR includes the promoter for $I G F 2 R$ antisense (also known 
as Air) that silences expression of $I G F 2 R$ (Sleutels et al., 2002). In mice, the ICR is hypermethylated on the maternal chromosome, preventing transcription of Air and allowing $I G F 2 R$ to be transcribed (Sleutels et al., 2002). On the paternal chromosome, the ICR is unmethylated, Air is expressed, and IGF2R is repressed (Ideraabdullah et al., 2008). In cattle, $I G F 2 R$ expression was also regulated by epigenetic modification of ICR, and in cloned calves, DNA methylation at the locus of gene imprinting was disrupted (Long and Cai, 2007). Consequently, DNA methylation of IGF2R ICR was assessed in the present study and our results show that the deceased transgenic cloned kids had increased levels of $I G F 2 R$ methylation in their lungs compared to the control. Furthermore, relative expression levels of $I G F 2 R$ in the lungs were examined by quantitative real-time PCR. IGF2R expression was significantly higher in the lungs of the deceased transgenic cloned kids than in the control. Hypermethylation of ICR in the lungs of the deceased transgenic kids may have caused lower Air expression and higher $I G F 2 R$ expression.

In contrast, Su et al. (2011) found that $I G F 2 R$ ICR was significantly hypomethylated in the placentas of deceased transgenic calves compared to controls. However, Zhao et al. (2012) reported that the imprinted gene $I G F 2 R$ exhibited relatively normal DNA methylation in the liver, kidneys, heart, muscles, and lungs of cloned sheep and controls. Why are these results so different? We can speculate that the IGF2R DMR is also site-specific or sequencespecific. Perhaps the methylation patterns of a few $\mathrm{CpG}$ sites in the $I G F 2 R$ DMR are heterogeneous on a single parental allele, or somatic nuclear transfer may have caused abnormal epigenetic reprogramming.

Embryo transfer is critical for the production of transgenic cloned animals. Our method consisted of transferring reconstructed embryos to a surrogate's oviducts at the 2 to 8 cell stage instead of implanting blastocyst stage embryos into the uterine horn, and consequently, six live kids were successfully produced. To identify whether the deceased goats were derived from the gene-transferred somatic cells, microsatellite analysis was conducted using five primer pairs, which showed that the genotypes of the cloned goats were the same as the donor cell, but different from the pregnant goat. Furthermore, using PCR and DNA sequence analysis, it was confirmed that the three deceased cloned goats had transgenic integration of the $h L F$ exogene.

In conclusion, in the present study, it was confirmed that the $h L F$ gene was integrated and the donor cell and the deceased cloned dairy goats had the same genotype. In addition, in contrast to the control, the IGF2R gene in the lungs of deceased kids showed abnormal hypermethylation and higher expression, which indicates that incomplete or abnormal DNA methylation epigenetic reprogramming of the imprinting gene IGF2R in the lungs may be one of the causes of abnormal development and the death of the transgenic cloned goats.

\section{Conflicts of interest}

The authors declare no conflict of interest.

\section{ACKNOWLEDGMENTS}

Research supported by the Fundamental Research Funds for the Central Universities (\#KYZ201211) and the National Major Special Projects on New Cultivation for Transgenic Organisms (\#2014ZX08008-004 and \#2014ZX08008-003). 


\section{REFERENCES}

Behboodi E, Memili E, Melican DT, Destrempes MM, et al. (2004). Viable transgenic goats derived from skin cells. Transgenic Res. 13: 215-224.

Bondioli K, Ramsoondar J, Williams B, Costa C, et al. (2001). Cloned pigs generated from cultured skin fibroblasts derived from a H-transferase transgenic boar. Mol. Reprod. Dev. 60: 189-195.

Chen DY, Jiang MX, Zhao ZJ, Wang HL, et al. (2007). Cloning of Asian yellow goat (C. hircus) by somatic cell nuclear transfer: telophase enucleation combined with whole cell intracytoplasmic injection. Mol. Reprod. Dev. 74: 28-34.

Cibelli JB, Stice SL, Golueke PJ, Kane JJ, et al. (1998). Cloned transgenic calves produced from nonquiescent fetal fibroblasts. Science 280: 1256-1258.

Feng YQ, Desprat R, Fu H, Olivier E, et al. (2006). DNA methylation supports intrinsic epigenetic memory in mammalian cells. PLOS Genet. 2: e65.

Gardiner-Garden M and Frommer M (1987). CpG islands in vertebrate genomes. J. Mol. Biol. 196: 261-282.

Huang YJ, Huang Y, Baldassarre H, Wang B, et al. (2007). Recombinant human butyrylcholinesterase from milk of transgenic animals to protect against organophosphate poisoning. Proc. Natl. Acad. Sci. U.S.A. 104: 13603-13608.

Ideraabdullah FY, Vigneau S and Bartolomei MS (2008). Genomic imprinting mechanisms in mammals. Mutat. Res. Fundam. Mol. Mech. Mutagen. 647: 77-85.

Jaenisch R and Bird A (2003). Epigenetic regulation of gene expression: how the genome integrates intrinsic and environmental signals. Nat. Genet. 33: 245-254

Jang G, Bhuiyan MMU, Jeon HY, Ko KH, et al. (2006). An approach for producing transgenic cloned cows by nuclear transfer of cells transfected with human alpha 1-antitrypsin gene. Theriogenology 65: 1800-1812.

Lazaris A, Keyston R, Karatzas CN and Keefer CL (2006). Transgenesis using nuclear transfer in goats. Methods Mol. Biol. 348: 213-225.

Li S, Li Y, Yu S, Du W, et al. (2007). Expression of insulin-like growth factors systems in cloned cattle dead within hours after birth. Mol. Reprod. Dev. 74: 397-402.

Long JE and Cai X (2007). Igf-2r expression regulated by epigenetic modification and the locus of gene imprinting disrupted in cloned cattle. Gene 388: 125-134.

Meng L, Zhang Y, Xu X, Wang Z, et al. (2011). Construction and identification of mammary expressional vector for cDNA of human lactoferrin. Chin. J. Biotechnol. 27: 253-261.

Sleutels F, Zwart R and Barlow DP (2002). The non-coding Air RNA is required for silencing autosomal imprinted genes. Nature 415: 810-813.

Su JM, Yang B, Wang YS, Li YY, et al. (2011). Expression and methylation status of imprinted genes in placentas of deceased and live cloned transgenic calves. Theriogenology 75: 1346-1359.

Suteevun-Phermthai T, Curchoe CL, Evans AC, Boland E, et al. (2009). Allelic switching of the imprinted IGF2R gene in cloned bovine fetuses and calves. Anim. Reprod. Sci. 116: 19-27.

Wei Y, Zhu J, Huan Y, Liu Z, et al. (2010). Aberrant expression and methylation status of putatively imprinted genes in placenta of cloned piglets. Cell Reprogramm. 12: 213-222.

Xing B, Xu Y, Cheng Y, Liu H, et al. (2007). Overexpression of IGF2R and IGF1R mRNA in SCNT-produced goats survived to adulthood. J. Genet. Genomics 34: 709-719.

Yang X, Smith SL, Tian XC, Lewin HA, et al. (2007). Nuclear reprogramming of cloned embryos and its implications for therapeutic cloning. Nat. Genet. 39: 295-302.

Young LE, Fernandes K, McEvoy TG, Butterwith SC, et al. (2001). Epigenetic change in IGF2R is associated with fetal overgrowth after sheep embryo culture. Nat. Genet. 27: 153-154.

Zhang L, Wang SH, Dai YP and Li N (2009). Aberrant gene expression in deceased transgenic cloned calves. Anim. Reprod. Sci. 112: 182-189.

Zhang YL, Wan YJ, Wang ZY, Xu D, et al. (2010). Production of dairy goat embryos, by nuclear transfer, transgenic for human acid beta-glucosidase. Theriogenology 73: 681-690.

Zhao LX, Zhao GP, Guo RQ, Zhang D, et al. (2012). DNA methylation status in tissues of sheep clones. Reprod. Domest. Anim. 47: 504-512. 